\title{
Quality Assurance Matrix as the advanced generation of quality control
}

\author{
Nadia Belu ${ }^{1,}{ }^{*}$, Agnieszka Misztal $^{2}$ and Laurentiu Mihai lonescu ${ }^{3}$ \\ ${ }^{1}$ University of Piteşti, Faculty of Mechanics and Technology, 110040 Pitesti, Targul din Vale \\ Street, No. 1, Argeş, Romania \\ 2 Poznan University of Technology, Faculty Engineering Management, Strzelecka 11, \\ 60-965 Poznan, Poland \\ ${ }^{3}$ University of Pitesti, Faculty of Electronics, Communcations and Computers, Str. Targu din \\ Vale, nr.1, 110040, Pitesti, Romania \\ "nadia.belu@gmail.com
}

\begin{abstract}
Presently, in the automotive industry, continuous improvement of product and process quality is always challenging and creative task. Many quality techniques were adopted in this field and advantages were also gained. The intention of this paper is to present the possibilities that offers the use of quality control and Quality Assurance Matrix to provide largest protection against nonconformities in the production process. Are presented the similarities and differences between the traditional quality control and modern control using QAM. By adopting QAM in the design stage and serial production line itself leads to launch of a product with maximum quality performance, with tighter tolerances, and with reduced or no defects.
\end{abstract}

Keywords: quality control, quality assurance matrix, quality management, risk

\section{Introduction}

The growing requirements of car users cause that in recent years more and more manufacturers make efforts to ensure product reliability. The companies have to adapt their products precisely to customer needs, and therefore parameters of manufactured products are adjusted to the individual requirements of customers. Different customers determine their specific requirements based on their special market strategy in order to satisfy customers' needs [1]. This involves technologically advanced process design, quality planning and quality control throughout the production cycle [2, 3, 4]. Existing tools and methods have become inadequate because they do not meet all additional requirements. It is therefore necessary to look for new solutions or improve old and trusted methods. A new quality control tool risk-based thinking in the procedural approach has the goal of achieving improved results and preventing negative effects. Thus, Quality Assurance Matrix is a modern identification tool of the problems, a standardized process that takes potential or actual quality concerns, ranks their importance to customer satisfaction and evaluates the robustness of the manufacturing and inspection processes against the potential or actual seriousness of the concern. Management of the processes can be achieved using the PDCA cycle.

\section{Quality control aims}

Quality control includes monitoring processes (understood as a permanent tracking and transmission of information), and eliminating the causes of unsatisfactory performance on some or all stages of the life cycle of the product. For the purpose of distinguishing the range of impact, it was adopted the concept of quality control circuits. There are following [5]: 
a) small (short) circuits of quality control, directly using data from the measuring instruments and the information minimally processed (found mainly in the area of production and focus on a particular position or group of positions and carried out technological operations, for example. Shewhart control cards),

b) local (medium) circuits of quality control in a small way using direct measurement data, and supplied most of all information pre-processed (beyond the workplace, or lines, or slot, operate in one or several related steps, are focused on a particular product or technological process, decisions are made on the basis of periodic reports, departmental or project survey results),

c) extensive (long) circuits controlling quality, characterized by a long-time collection and a high degree of processing of data and information used for decision-making control (cover the entire life cycle of the product; their goal is to identify the general regularities occurring in different areas of the company, as well as on the market the consumer - in relation to quality.

Traditional quality control is based on the following ten steps [5]:

1. determining the rank of the problem, its nature and the objective and evaluation criteria for its solution,

2. collection of data necessary to verify the hypotheses,

3. making hypotheses about the causes,

4. verification of hypotheses on the basis of the collected data,

5. acceptance of the most likely causes of a problem,

6. choosing the solution that is most likely to bring the desired effect,

7. preparing a plan to introduce a solution, providing resources for implementation,

8. identifying potential threats,

9. introduction of solutions,

10. checking the efficiency of implemented solutions.

Traditional tools of quality usually served to data collection and processing. They were based on earlier developed quality plan $[6,7,8]$.

With a stable process the spread of common cause variation will be within certain limits. These limits are not the specification limits but are limits of natural variability of the process. These limits can be calculated and are referred to as the upper and lower control limits (UCL and LCL, respectively). The control limits may be outside the upper and lower specification limits to start with but as common causes are eliminated, they close in and eventually the spread of variation is all within the specification limits [9]. Any variation outside the control limits will be rare and will signal the need for corrective action (fig. 1).

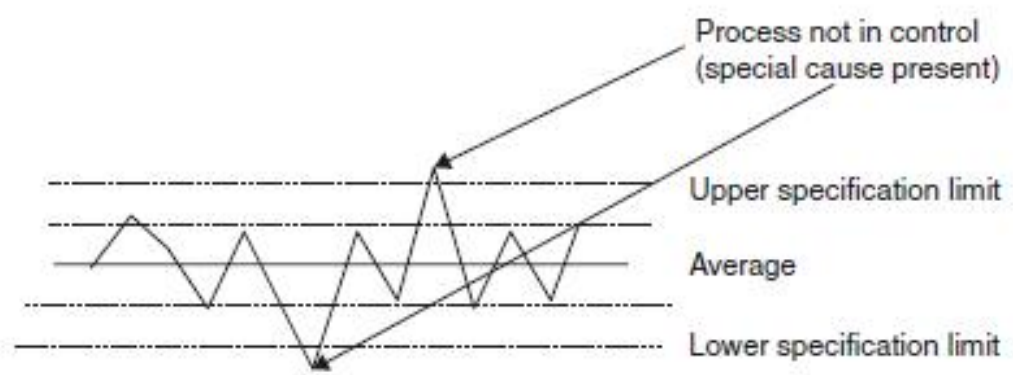

Fig. 1 Control and specification limits [10]

Quality Assessment Matrix is suitable for the continuous control of the parameters of the product. 


\section{Quality Assurance Matrix}

Quality Assurance Matrix (QAM) is a quality tool that is based on the principle that any failure (noncompliance) to a manufacturing process that affects a customer (who may be the next process or final customer) must imperatively be eradicated. The method ranks, for potential and existing defects, the reliability limits of the control systems in the manufacturing process, thus allowing the implementation a necessary corrective measures and achieving in this way a quality objectives [11]. Quality Assurance Matrix (QM) helps to achieve the goal of meeting Customer Quality Expectations such as [12]:

1. QM enables control of all critical, significant and / or important items on the vehicle;

2. QM is a useful problem identification tool.

This tool is used for:

1. new model process planning,

2. current model quality concerns.

Quality Mapping uses some of the Failure Modes and Effects Analysis (FMEA) thought processes - Risk Assessment. Ultimate aims of this tool are:

- robust products and design,

- robust manufacturing processes delivered through In-Station Process Control,

- operator interface with process and product which assures quality of output,

- engaging the intelligence of the total organization in pursuit of customer satisfaction.

QA matrix reflecting the declination product / process is in general in a single physical manufacturing line. The Matrix QA is a land management tool under the guidance of the first management level (after the operator).

To capitalize more easily from one project to another, a matrix QA will be conducted by vehicle / body / piece.

The matrix may be used:

- in life series on proven cases to synthesize the actual situation and improve it,

- in life series on potential problems when the actual situation is sufficiently controlled,

- project to identify the establishment of controls on the identification of risks.

Note: in order of priority, the MQA POE first concern problems found, but wait for the goals of a few ppm (parts per million), it is important to integrate the potential problems in connection with the risk analysis. Shape of QA Matrix is showed on picture 1. 


\begin{tabular}{|c|c|c|}
\hline \multicolumn{2}{|c|}{ DEECIS QUOIAIIOM } & VareI CIEMI \\
\hline DEGRII & Grave & 5 \\
\hline B & very annoying & 3 \\
\hline C & annoying & 1 \\
\hline
\end{tabular}
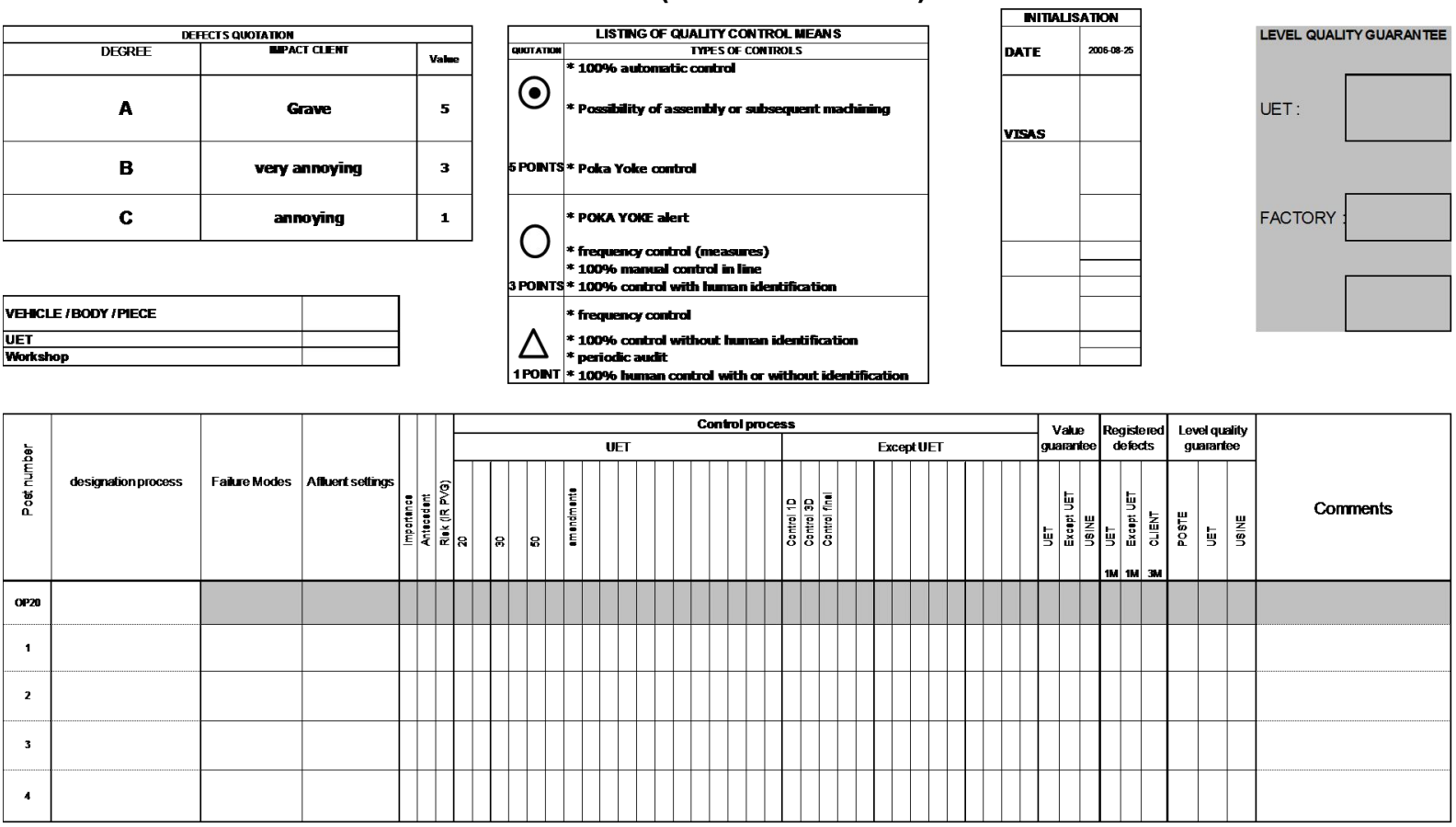

Fig. 1. Shape of QAM

We can distinguish many similarities but also major differences between the traditional quality control and modern control using QAM. These characteristics are summarized in Table 1.

Table 1. Comparison of traditional and contemporary quality control

\begin{tabular}{|c|c|c|}
\hline Characteristics & Traditional quality control & QAM \\
\hline aim & $\begin{array}{l}\text { - minimizing the number of } \\
\text { non-conforming products } \\
\text { - adjustment of the production } \\
\text { process }\end{array}$ & $\begin{array}{l}\text { - to master the delivery rate of conformity } \\
\text { (ppm) } \\
\text { - to insure the robust treatment of the } \\
\text { product's quality problems } \\
\text { - performed to meet a customer } \\
\text { requirement and/or to comply with safety } \\
\text { and quality requirements }\end{array}$ \\
\hline assumption & $\begin{array}{l}\text { process monitoring and } \\
\text { eliminating the causes of } \\
\text { unsatisfactory performance at } \\
\text { all stages of the life cycle of the } \\
\text { product }\end{array}$ & $\begin{array}{l}\text { any failure with a potential effect on the } \\
\text { customer must be eradicated }\end{array}$ \\
\hline condition & the process must be stable & $\begin{array}{l}\text { - in the serial production on the proven } \\
\text { defect, analysis and improvement of real } \\
\text { situation } \\
\text { - in the serial production on the potential } \\
\text { defects when the real situation is stable } \\
\text { - in the projects during the definition phase } \\
\text { and startup of the production process }\end{array}$ \\
\hline principle of action & $\begin{array}{l}\text { assess variability of process } \\
\text { parameters }\end{array}$ & $\begin{array}{l}\text { interactive method for dealing with the } \\
\text { already arisen defects in the production } \\
\text { process }\end{array}$ \\
\hline interaction object & $\begin{array}{l}\text { - product (quality features) } \\
\text { - machine (ability qualitative) }\end{array}$ & $\begin{array}{l}\text { - product (quality features) } \\
\text { - production process parameters }\end{array}$ \\
\hline using methods & - Shewarts sheets & - PDCA \\
\hline
\end{tabular}




\begin{tabular}{|c|c|c|}
\hline & - histogram & $\begin{array}{l}\text { - Poka Yoke } \\
\text { - FMEA } \\
\text { - risk assessment } \\
\text { - QRQC - Quick Response Quality } \\
\text { Control, Quality Control Story } \\
\text { - Fault tree analysis, Control Plan }\end{array}$ \\
\hline measured values & $\begin{array}{l}\text { - average value } \\
\text { - variety } \\
\text { - standard deviation } \\
\text { - median }\end{array}$ & $\begin{array}{l}\text {-unlimited number of characteristics } \\
\text { - overall level quality guarantee }\end{array}$ \\
\hline type of evaluation & subjective & objective \\
\hline flexibility of tests & low & high \\
\hline $\begin{array}{l}\text { response to } \\
\text { problems }\end{array}$ & $\begin{array}{l}\text { only those that correspond to } \\
\text { measured characteristics }\end{array}$ & unlimited range \\
\hline $\begin{array}{l}\text { possibility of } \\
\text { improvement } \\
\text { activities }\end{array}$ & no & yes \\
\hline actors involved & quality engineers & $\begin{array}{l}\text { multidisciplinary team (quality, } \\
\text { maintenance, engineering) }\end{array}$ \\
\hline costs & $\begin{array}{l}\text { reduces the number of rejects } \\
\text { and saves the cost of material }\end{array}$ & $\begin{array}{l}\text { decreases development time and re-design } \\
\text { costs }\end{array}$ \\
\hline customer & $\begin{array}{l}\text { improves the relationship with } \\
\text { the customer }\end{array}$ & enhanced customer satisfaction \\
\hline
\end{tabular}

Characteristics summarized in Table 1 show that Quality Assurance Matrix is a highly developed form of quality control. This corresponds fully the idea of continuous improvement and allows for the involvement of a multidisciplinary team to continuously improve the quality of products and processes.

\section{Conclusions}

The enterprise from the automotive sector must use the methods which will help them to enhance processes and activities in the whole production cycle, for a new level of performance regarding employees, products, processes and management. The employees should be encouraged and trained to use the new tools especially in the automotive sector due to the growing demand and expectation of customers. The application and benefits of Quality Assurance Matrix can be further explored in the automotive industry.

\section{References}

[1] Doshi J. A., Desai D., Overview of Automotive Core Tools: Applications and Benefits, Journal of The Institution of Engineers (India): Series C, (2016), p. 1-12.

[2] Mrugalska B., Akielaszek-Witczak A., Stetter R., Robust quality control of products with experimental design, 2014 International Conference on Production Research - Regional Conference Africa, Europe and The Middle East and 3rd International Conference on Quality and Innovation in Engineering and Management (ICPR-AEM 2014), p. 343-348.

[3] Misztal A., Belu N., Rachieru N., Comparative analysis of awareness and knowledge of APQP requirements in Polish and Romanian automotive industry, Applied Mechanics and Materials, Vol. 657 (2014) pp. 981-985

[4] Gołaś H., Mazur A., Mrugalska B., Application of risk analysis and quality control methods for improvement of lead molding process, Metalurgija Vol. 55 Iss. 4 p. 811-814. 
[5] Hamrol A., Mantura W., Zarządzanie jakością, Politechnika Poznańska, Poznań 2005.

[6] Misztal A., Bachorz S., Quality planning of parts machine production based on housing of cylinder head milling machines, Applied Mechanics and Materials, Vol. 657 (2014) p. 986990.

[7] Czyżewski B., Metody statystyczne w sterowaniu jakością procesów technologicznych, Zeszyty Naukowe Politechniki Poznańskiej seria Organizacja i Zarządzanie, nr 46/2007, p. 63-87.

[8] Jasiulewicz-Kaczmarek M., Saniuk A., 2015, Human factor in Sustainable Manufacturing, Editors: M. Antona, C. Stephanidis, Universal Access in Human-Computer Interaction. Access to the Human Environment and Culture, LNCS Vol. 9178, pp.444 - 455.

[9] Hoyle D., Automotive quality systems handbook, Elsevier, Burlington 2005.

[10] Boroiu A., Jan G., Bălteanu A., Bâldea M., Boroiu A., Possibilities to weighting the global indicators of quality determined with the quality assurance matrix, The Scientific Bulletin of Valahia University - Materials and Mechanics - No. 10 (year 13) 2015, p. 154156.

[11] Ştirbu L., Belu N., Bondoc M.D., Quality assurance matrix in automotive industry, Annals of the Oradea University. Fascicle of Management and Technological Engineering, Volume XI (XXI), 2012, No. 2.

[12] Schwab K., Holistic Methodological Model for introducing Industrial Quality Management Methods to Manufacturing in Small and Medium Sized Enterprises, Procedia Engineering 63 (2013) p. 895 - 902. 